\title{
Market timing and selectivity performance of mutual funds in Ghana
}

\author{
Abubakar Musah ${ }^{a^{*}}$, Damankah Basil Senyo and Eliasu Nuhu ${ }^{\text {b }}$
}

${ }^{a}$ Department of Finance, University of Ghana Business School, P. O. Box LG 78, Legon, Accra-Ghana ${ }^{b}$ Department of Accounting and Finance, Islamic University College, Ghana

\section{H R O N I C L E}

\section{Article history:}

Received January 14, 2014

Accepted 10 June 2014

Available online

June 202014

Keywords:

Market timing

Selectivity

Mutual funds

Managers

Market return

Ghana

\section{A B S T R A C T}

The growing interest in mutual funds in Ghana has been tremendous over the last decade as evidenced by the continuous increases in number and total funds under management. However, no empirical work has been done on the selectivity and timing ability of the mutual fund managers. Using monthly returns data hand-collected from the reports of the mutual fund managers for the period January 2007-December 2012, this paper examines the market timing and selectivity ability of mutual fund managers in Ghana using the classic Treynor-Mazuy (1966) model and Henriksson- Merton (1981) model. The results suggest that, in general mutual fund managers in Ghana are not able to effectively select stocks and also are not able to predict both the magnitude and direction of future market returns. More specifically, all of the sample mutual fund managers attain significant negative selectivity coefficients and also most of them attain insignificant negative timing coefficients.

2014 Growin

\section{Introduction}

The mutual fund industry is an essential part of the financial set up of every economy, be it emerging or developed. Given the role it plays by providing cheaper alternative avenues of investment for those who do not possess the technical expertise to identify potentially viable or financially feasible investment opportunities, its impact on the growth and development of an economy cannot be overlooked. It serves as a financial intermediary since it helps transfer funds from surplus spending units to deficit spending units. The importance of the industry is manifest in the growth in number as well as the value of funds under management of such schemes in the world, especially in the developed or advanced economies. In the US for example, there were over 8000 mutual funds with total assets of US\$14.7 trillion in 2012, an increase of US\$1.7 trillion over the 2011 figure (Investment Company Fact Book, 2013). Global mutual fund assets grew from US\$46.2 billion in 1990 (Tkac, 2001) to US\$ 26.8 trillion in 2012 (2013 Investment Company Fact Book). Managers of mutual funds are expected to make viable investment decisions with regards to the funds that have

\footnotetext{
*Corresponding author. Tel: +233243710245

E-mail addresses: sidiqitrust@gmail.com (A. Musah) 
been entrusted with them. Investors in mutual funds expect to earn returns commensurate with the level of risk that their funds have been exposed to. Making good returns for mutual fund investors is the work of the mutual fund managers. Predicting movements in the market returns and making wise investment decisions is therefore a core aspect of their job and many investors could be interested in knowing how well they are doing. Also important is the ability of the manager to select good stocks. This two activities form the core of investment management process.

According to Fama (1972), the forecasting skills of portfolio managers could be partitioned into two distinct components: macro-forecasting and micro-forecasting. Micro-forecasting involves managers' forecasts of price movements of selected individual stocks (i.e. selectivity or security analyses) whereas macro-forecasting involves managers' forecasts of price movements of the general stock market as a whole (i.e. market timing). This partitioning of forecasting skills is also evident in Treynor and Black (1973), who have shown that portfolio managers can effectively separate actions related to selectivity from those related to market timing. Stock selection is based on forecasts of company-specific activities and hence the prices of individual securities. It involves identifying undervalued stocks on the market and investing in those stocks. Market timing, however, refers to forecasts of future returns of the general stock market.

Ghana's economy has been hit by financial crisis in the past especially between 1983 and 1988. This led the economy to undergo tough reforms in order to strengthen the financial sector in the late 1980s and early 1990s. The Financial Sector Adjustment Programme (FINSAP) was launched in 1988 and one of the recommendations of FINSAP was the institution of a capital market. Since 1990 when the Ghana Stock Exchange started operation, there have been tremendous improvements in the financial sector in general. In 1996, the Databank EPACK (first mutual fund in Ghana) was introduced. This opened the mutual fund industry to the investment public in Ghana. Since the introduction of the EPACK, many improvements have been experienced in the industry. Total funds under management (net asset value) by mutual funds in Ghana stood at GHC172.8 million in 2012 (SEC Report, 2012). As at December 31, 2012, there were eighteen (18) licensed mutual funds but three (3) were not operational. All the eighteen were open ended funds. Total shareholder base was 167, 927 in 2012. Currently there are four main types of investment funds in Ghana-money market funds (invest mainly in the money market), equity funds (investing mainly in common stocks), balanced funds (investing both in stocks and bonds or money market) and real estate funds (investing in real estate). The Securities Industry Law (1993), PNDCL 333 governs the operation of the securities industry in Ghana. The Securities and Exchange Commission (SEC) is the regulatory body of the securities market in Ghana

Despite the growing number of mutual funds in Ghana, there is no published empirical work on the stock selectivity and market timing ability of the mutual fund managers. These issues have not been raised and remain a gap in the literature pertaining to Ghana. Our objective is to fill this gap. The recent discovery of oil is expected to speed up the growth of the economy and also provide more job opportunities for Ghanaians. In 2012 for example, the Ghanaian economy grew by 7.9\% (Ghana Statistical Service website: www.statsghana.gov.gh). Disposable incomes of workers are expected to increase and hence, the tendency of such beneficiaries to seek new investment opportunities. There is therefore the need to assess the performance of managers. This will allow us to know whether the managers are active or not. We therefore examine empirically the market timing and selectivity performance of eight (8) mutual funds in Ghana.

\section{Literature Review}

The literature on selectivity and market timing performance of mutual funds is enormous and varied. Whiles a group of researchers believe that aggregate stock market returns are predictable; others argue that there is scant evidence that investors actually take advantage of such predictability. Most 
researchers including Treynor and Mazuy (1966), Chang and Lewellen (1984), Henriksson (1984), Ken and Jen (1979), Chua and Woodward (1986), Connor and Korajzcyk (1986), Veite and Cheney (1982), Grinblatt and Titman (1988), Lockwood and Kadiyala (1988), Cumby and Glen (1990), Sinclair (1990), Coggin, Fabozzi and Rahman (1993), Gallo and Swanson (1996) and Daniel et al (1997) among others find little evidence of market timing among fund managers.

Jensen (1968) evaluated the ability of the fund managers in selecting the under-valued securities. He concluded that the fund managers of the sample of 115 Mutual funds were not able to forecast security prices well enough to recover research expenses and fees. Treynor and Mazuy (1966) developed a methodology for testing the market timing ability of Mutual fund managers following on Jensen's pioneering implementation of the capital asset pricing model (CAPM) to evaluate the performance of mutual funds. They had used 57 open-ended Mutual funds during the period of 19531962. They found no evidence that the investment managers of any of the 57 Mutual funds had successfully outguessed the market. Henriksson and Merton (1981) had developed a statistical measure for parametric and non-parametric tests of market timing ability of fund managers. They suggested that if any mutual fund manager has an ability to forecast the future observation and his forecasting was observable, the parametric test could be used without further assumptions on distribution of security returns. If manager's forecasting could not be observable, then the parametric test can be used under the assumption of either CAPM or multi factor return structure. These specifications permitted them to separate the gains of market timing skills. Using monthly data from February 1968 to June 1980, Henriksson (1984) found that only three funds had market timing ability at $5 \%$ significance level while only one fund had market timing ability at $1 \%$ significance level after he examined the market timing performance of 116 mutual funds.

Chua and Woodward (1986) examined the timing abilities of mutual funds in Canada, UK and US for the period 1973 - 1983. Their findings showed that mutual funds performed poorly in general in terms of market timing. Chang and Lewellen (1984) examined monthly returns of 67 mutual funds during the period January 1971 - December 1979 using the Henriksson - Merton parametric test. They concluded that managers are not able to time the market correctly. Keith et al (2010) test the market timing skills of UK equity and balanced mutual funds. They used regression based tests of Treynor-Mazuy and Henriksson-Merton. They find a relatively small number of funds (around 1\%) demonstrate positive market timing ability at a 5\% significance level while around $19 \%$ of funds exhibit negative timing and on average funds miss-time the market. However, controlling for publicly available information they find very little evidence of market timing ability based on private timing signals. In terms of investment styles, there are a small number of successful positive market timers amongst Equity Income and 'All Company' funds but not among either Small Stock funds or Balanced funds, although a few small stock funds are found to time a small stock index rather than a broad market index. Gupta (2001) made a study on Investment management of Mutual funds. His main emphasis was on the evaluation of the performance of Mutual fund schemes and testing of the market timing abilities of mutual fund managers over the period $1994-1999$. Results of the study showed that mutual funds have performed poorly and managers lack market timing skills. Cumby and Glen (1990) examined the performance of a sample of 15 US based internationally diversified mutual funds for the period 1982 - 1988 using (among others) the Treynor - Mazuy model. The results show that there exists a perverse timing effect. Nalini (2006) made a study on Market timing abilities and Mutual fund performance on equity linked saving schemes. Her study evaluates the market timing abilities of Indian fund managers of thirty-one tax planning schemes in India over the period 19952004. The study indicate that the fund managers have not been successful in reaping returns in excess of the market, rather they are timing the market in the wrong direction. Sanjay and Manoj (2008) evaluated the performance of selected equity based 57 Mutual fund schemes for the five year period 2000-2004. They conclude that the results showed timing ability, and to some extent stock selectivity improve when they use daily instead of monthly data. They feel that higher observation frequency captures the trading skills of more active fund managers in a better fashion. Koh, Phoon and Tan 
(1993) used both parametric (Henriksson - Merton (1981)) and non-parametric [Henriksson-Merton (1981), Henriksson-Lessard (1982)] approaches to examine market timing abilities of fund managers of six mutual funds and four investment companies in Singapore. The conclusions of the two approaches were contradictory. While the non-parametric approach led to the conclusion that market timing was achieved, the application of parametric approach led to opposite conclusions, thus market timing was not achieved. The authors tried to reconcile the empirical results and were eventually led to the conclusion that market timing abilities for the Singapore fund managers could not be ignored. By combining the APT performance evaluation method with the Treynor and Mazuy model to evaluate the performance of mutual fund managers, Lehmann and Modest (1987) found statistically measured abnormal timing and selectivity performance by mutual funds. They also found that performance measures are quite sensitive to the benchmark chosen and a large number of negative selectivity measures. Kon (1983) using switching regression techniques empirically examined the performance of mutual funds of 37 funds, 14 had overall timing estimates that were positive but none was statistically significant. This means that the managers did not exhibit any timing skills over the evaluation period. Lockwood and Kadiyala (1988) developed a generalization of the Hildreth and Hoyck (1968) random coefficient model for use in evaluating the macro-forecasting ability of portfolio managers. In this model the superior manager adjusts beta period by period according to changing market conditions. Monthly returns for 47 US mutual funds over a 192 month period from January 1964 through 1979 were examined. The conclusions were that fund managers failed the suggested macro-forecasting (market timing) test, betas change randomly in many funds and certain funds exhibit superior micro-forecasting (selectivity). Coggin, Fabozzi and Rahman (1993) examined the performance of 71 equity pesions fund managers in the US over the period January 1983 through December 1990 within the framework of Treynor - Mazuy (1966) and Bhattacharya - Pfleiderer (1983). The results suggest that pension fund managers are on average better stock pickers than market timers. More specifically, the average selectivity measure is positive and the average timing measure is negative irrespective of the choice of benchmark portfolio or estimation model. Gallo and Swanson (1996) examined a series of international mutual funds and concluded that fund managers are not market timing capable, though they showed some level of selectivity. Surinder (2011) analyzed the market timing ability of Indian mutual fund managers for the period of 1999-2004. The study found out that Indian mutual fund managers are unable to test the market timing of the mutual fund schemes and relying only on stock selection skill for getting maximum return and that, it implies that they are generating superior performance due to largely involvement in security selection. Nikolaos (2002) analysed the market timing and selectivity within the framework suggested by Treynor and Mazuy (1966) and Henriksson and Merton (1981). The study found out that evidence does not provide support for correct timing, irrespectively of how the returns of the market index are calculated and that using the Total Performance Index reduces the ability of managers for selectivity. This result holds for both the models utilized in the study. Tihana (2013) also finds no market timing abilities by the ten selected Croatian mutual fund managers within the framework of the TreynorMazuy and Henriksson-Merton frameworks.

\section{Methodology}

In order to examine the timing ability of Ghanaian mutual fund managers, we use two modules - one of them was proposed by Treynor and Mazuy (1966) and the other one was proposed by Henrikson and Merton (1981) to test the market timing abilities of Ghanaian mutual fund managers. Treynor and Mazuy (1966) and Admati et al (1986) measures market timing by adding a quadratic term to the Jensen $(1968,1969)$ model to capture the timing skills of fund managers. Their model is presented below as equation (1)

$\left(R_{p, t}-R_{f, t}\right)=\alpha_{p}+\beta_{p}\left(R_{m, t}-R_{f, t}\right)+\gamma_{p}^{T M}\left(R_{m, t}-R_{f, t}\right)^{2}+\varepsilon_{p, t}$

where;

$D$ is a dummy variable that equals 0 for $\left(\mathrm{R}_{\mathrm{m}}>\mathrm{R}_{\mathrm{f}}\right)$ and 1 for $\left(\mathrm{R}_{\mathrm{m}}<\mathrm{R}_{\mathrm{f}}\right)$ 
$\left(R_{p, t}-R_{f, t}\right)$ is the simple excess return on portfolio $\mathrm{p}$ in period $t$

$\left(R_{m, t}-R_{f, t}\right)$ is the simple excess return on the market portfolio in period $t$

$\alpha_{p}$ is a measure of the selectivity skills of the manager of portfolio $\mathrm{p}$

$\beta_{p}$ is the systematic risk measure of portfolio $\mathrm{p}$

$\gamma_{p}^{T M}$ is the Henriksson-Merton measure of the market-timing skill of the manager of portfolio $P$,

$\varepsilon_{p, t}$ is the error term with the following CAPM conditions: $E\left(\varepsilon_{p, t}\right)=0, E\left(\varepsilon_{p, t} \mid \varepsilon_{p, t-1}\right)=0$.

The emphasis in this model is on the coefficient term $\gamma^{T M}$ which is a measure of the market timing component of the mutual fund performance. The model allows an assessment of the ability of managers to buy or sell high or low beta firms as the market environment changes. The model of Treynor and Mazuy assumes that managers possess private information about how large or small the market return will be and linearly deviates from their own past exposure to the market. Henriksson and Merton (1981) believe that managers only possess private information about the future direction but not the magnitude of the market returns. They therefore formulate their model as follows:

$$
\left(R_{p, t}-R_{f, t}\right)=\alpha_{p}+\beta_{p}\left(R_{m, t}-R_{f, t}\right)+\gamma_{p}^{T M}\left[D\left(R_{m, t}-R_{f, t}\right)\right]+\varepsilon_{p, t}
$$

where;

$\mathrm{D}$ is a dummy variable that equals 0 for $\left(\mathrm{R}_{\mathrm{m}}>\mathrm{R}_{\mathrm{f}}\right)$ and 1 for $\left(\mathrm{R}_{\mathrm{m}}<\mathrm{R}_{\mathrm{f}}\right)$

$\left(R_{p, t}-R_{f, t}\right)$ is the simple excess return on portfolio $\mathrm{p}$ in period $t$

$\left(R_{m, t}-R_{f, t}\right)$ is the simple excess return on the market portfolio in period $t$

$\alpha_{p}$ is a measure of the selectivity skills of the manager of portfolio $\mathrm{p}$

$\beta_{p}$ is the systematic risk measure of portfolio $\mathrm{p}$

$\gamma_{p}^{T M}$ is the Henriksson-Merton measure of the market-timing skill of the manager of portfolio $P$,

$\varepsilon_{p, t}$ is the error term with the following CAPM conditions: $E\left(\varepsilon_{p, t}\right)=0, E\left(\varepsilon_{p, t} \mid \varepsilon_{p, t-1}\right)=0$.

This model includes a dummy that takes a value of one when the excess market return is positive and a value of zero when the excess market return is negative. These two regressions are run to examine the market timing ability of Ghanaian CIS managers.

\subsection{Sample and Data}

Monthly data on returns of eight mutual funds (equity and balanced) were collected from market reports of the funds for the period January 2007 to December 2012. To be included in the sample, each fund must have existed throughout the 60 month period. A market benchmark is required for the computation of the Treynor-Mazuy and the Henriksson-Merton models. We used the Ghana Stock Exchange composite index (GSE-CI) as the market benchmark portfolio. The GSE-CI for the study period January 2007 to December 2012 was downloaded from the Bank of Ghana website. Also required in the calculation is a return on a risk-free asset. In this study, a 91-day Treasury Bills was used as the risk-free asset. The monthly rates were also downloaded from the Bank of Ghana website (www.bog.gov.gh).

\section{Discussion of findings}

The results suggest that mutual funds in Ghana perform poorly in terms of selectivity and market timing. They are not able to predict the direction and magnitude of market returns as evidenced by the results of the Treynor-Mazuy model and Henriksson-Merton model. Only funds that invest in the 
market (stocks) were considered in the estimations. The tables below present regression results of the Henriksson-Merton model and the Treynor-Mazuy model for Ghanaian CIS for the period 2007-2012 using monthly data hand collected and data from the Bank of Ghana website. The benchmark market portfolio is the GSE-CI and the risk-free asset is the 91-Day Treasury bills.

\subsection{Treynor-Mazuy Model}

Table 4.1 below presents the results of the Treynor-Mazuy model. The results do not show encouraging impressions about the Ghanaian mutual fund market, as the market timing coefficient is not significant for six of the eight mutual funds suggesting that the managers of mutual funds in Ghana are not able to predict the magnitude or quantum of market returns. In other words, they do not engage in market timing activities. Fund 1 and fund 3 were the only funds with significant timing coefficients.

Table 1

$\underline{\text { Results of Treynor-Mazuy Model }}$

\begin{tabular}{|c|c|c|c|c|}
\hline Fund & $\alpha_{p}$ & $\beta_{\mathrm{p}}$ & $\gamma_{p}^{T M}$ & Adj. $R^{2}$ \\
\hline \multirow[t]{2}{*}{1} & $0.357^{*}$ & $0.368 *$ & $0.095^{*}$ & 0.681 \\
\hline & $(2.069)$ & $(4.614)$ & $(2.245)$ & \\
\hline \multirow[t]{2}{*}{2} & $-2.446^{*}$ & $0.581 *$ & -2.521 & 0.713 \\
\hline & $(-3.534)$ & $(2.711)$ & $(-0.783)$ & \\
\hline \multirow[t]{2}{*}{3} & $-9.405^{*}$ & $0.633^{*}$ & $0.000 *$ & 0.624 \\
\hline & $(-5.117)$ & (3.994) & $(-3.764)$ & \\
\hline \multirow[t]{2}{*}{4} & $-2.457^{*}$ & $0.279^{*}$ & -0.001 & 0.741 \\
\hline & $(-6.072)$ & (4.962) & $(-1.021)$ & \\
\hline \multirow[t]{2}{*}{5} & $3.671 *$ & $0.773^{*}$ & -7.405 & 0.698 \\
\hline & $(4.835)$ & $(5.007)$ & $(-0.107)$ & \\
\hline \multirow[t]{2}{*}{6} & $-4.673^{*}$ & $0.718^{*}$ & 0.026 & 0.669 \\
\hline & $(-3.864)$ & $(3.167)$ & $(0.534)$ & \\
\hline \multirow[t]{2}{*}{7} & $-10.272^{*}$ & $0.521^{*}$ & 0.682 & 0.686 \\
\hline & $(-3.268)$ & $(2.94)$ & $(1.298)$ & \\
\hline \multirow[t]{2}{*}{8} & $-4.351 *$ & $0.653^{*}$ & -1.309 & 0.346 \\
\hline & $(-5.315)$ & $(3.067)$ & $(-0.010)$ & \\
\hline
\end{tabular}

*Significant @ $5 \%$ (t-statics in brackets)

Table 1 further shows that fund 1 and fund 5 recorded positive alpha values suggesting superior stock selection abilities (micro-forecasting) by the managers of the funds. The rest of the funds achieved significant negative alphas suggesting that their stock selection activities yield negative results for the investors. It actually suggests that managers are doing worse than a passive strategy (random buyand-hold policy). This, however, could be due to the poor performance of the stock market itself over the evaluation period. The stock market recorded an average return of -3.35 with a high total risk (standard deviation) of 11.99 and a Sharpe ratio of -1.62. The mutual funds performed worse because of management and operation cost of the funds.

\subsection{Henriksson-Merton model}

The estimated parameters of the Henriksson-Merton market timing model (table 4.2) also shows absence of market timing amongst seven of the funds suggesting that managers are unable to or do not possess private information to enable them predict the direction of future market returns. Only fund 1 was able to predict the direction of market returns as expected since the managers were able to guess the magnitude of the market returns (referring to Table 2). All the other CISs achieved negative timing (although not statistically significant) coefficients suggesting that managers misread the movement of market returns directions. Table 2 below presents the results of the Henriksson-Merton model. 
Table 2

Results of Henriksson-Merton Model

\begin{tabular}{|c|c|c|c|c|}
\hline Fund & $\alpha_{p}$ & $\beta_{\mathrm{p}}$ & $\gamma_{p}^{T M}$ & Adj. $\mathrm{R}^{2}$ \\
\hline \multirow[t]{2}{*}{1} & $-1.902 *$ & $0.440^{*}$ & $0.101 *$ & 0.571 \\
\hline & $(-3.045)$ & $(7.271)$ & $(4.424)$ & \\
\hline \multirow[t]{2}{*}{2} & $-2.496^{*}$ & $0.458^{*}$ & -1.225 & 0.672 \\
\hline & $(-3.704)$ & $(4.178)$ & $(-1.661)$ & \\
\hline \multirow[t]{2}{*}{3} & $-5.842 *$ & -0.421 & -3.525 & 0.583 \\
\hline & $(-4.620)$ & $(-0.899)$ & $(-1.446)$ & \\
\hline \multirow[t]{2}{*}{4} & $-5.183^{*}$ & -0.379 & -0.408 & 0.721 \\
\hline & $(-4.009)$ & $(-1.845)$ & $(-1.103)$ & \\
\hline \multirow[t]{2}{*}{5} & $-2.047^{*}$ & $0.141^{*}$ & -3.525 & 0.652 \\
\hline & $(-2.79)$ & $(3.846)$ & $(-1.446)$ & \\
\hline \multirow[t]{2}{*}{6} & $-3.673 *$ & 0.178 & -0.534 & 0.722 \\
\hline & $(-8.643)$ & $(1.367)$ & $(-1.228)$ & \\
\hline \multirow[t]{2}{*}{7} & $-2.626^{*}$ & $0.300^{*}$ & -4.921 & 0.653 \\
\hline & $(-4.246)$ & $(3.071)$ & $(-1.627)$ & \\
\hline \multirow[t]{2}{*}{8} & -6.182 & -0.682 & -9.906 & 0.553 \\
\hline & $(-1.300)$ & $(-1.100)$ & $(-1.031)$ & \\
\hline
\end{tabular}

*Significant @ 5\% (t-statics in brackets)

The selectivity coefficients are still negative and significant for all funds except fund 8 (whose negative alpha was not significant), indicating poor micro-forecasting skills of the managers of the CISs. This could be due to the small number of listed stocks on the Ghana Stock Exchange and also the poor performance of the stocks over the evaluation period. As at December 31, 2012, there were 34 listed equities on the stock GSE.

\section{Summary and Conclusion}

The forecasting ability of mutual fund managers were examined using the models proposed by Treynor and Mazuy (1966) and Henriksson and Merton (1981). The results of the Treynor-Mazuy model shows only one mutual fund representing $12 \%$ of the funds achieved a significant positive timing coefficient and also one fund achieved a significant positive alpha when the HenrikssonMerton model was used. The mutual fund managers in Ghana have also shown negative selectivity as the alphas, measuring the selectivity of managers were negative and significant in $75 \%$ of the funds used for the study under the Treynor-Mazuy model. Under the Henriksson-Merton model, the alpha was negative in all funds and significant in seven of them. This shows that, overall, managers of mutual funds are not able to effectively select good stocks. The results indicate that Ghanaian fund managers are not seriously engaged in any macro forecasting or market timing and neither are they effectively involved in stock selection. They are not able to predict both the direction and magnitude of future market returns. Overall, the performance of funds in Ghana has not been good over the period 2007-2012. Most of the previous works in the literature finds little evidence that fund managers possess market timing ability. Jensen (1968), Keith et al (2010), These findings are consistent with previous works such as Chang and Lewellen (1984), Henriksson (1984), Chua and Woodward (1986), Connor and Korajzcyk (1986), Grinblatt and Titman (1988), Kadiyala and Lockwood (1988), Cumby and Glen (1990), Sinclair (1990), Coggin - Fabozzi and Rahman (1993), and Gallo and Swanson (1996), who find little evidence of market timing performance of mutual funds and many other studies found poor market timing of investment managers.

\section{References}

Admati, A. R., Bhattacharaya, S., Pfleildrer, P. \& Ross, S. A. (1986). On timing and selectivity. Journal of Finance, 16(3), 715-732.

Amitabh, G. (2001). Mutual funds in India: A study of investment management. Finance India, 15(2), 631-637.

Bhattacharya S. \& Pfleiderer, P. (1983). A note on performance evaluation. Technical Report 714 Stanford, California: Stanford University, Graduate School of Business. 
Chang, E. \& Lewellen, W. (1984). Market timing and mutual fund investment performance. The Journal of Business, 57, 57-72.

Chua J. H. \& Woodward, R. S. (1986). Gains from Market Timing. Monograph No 1986 - 2, New York University.

Coggin, T. D., Fabozzi, F. J., \& Rahman, S. (1993). The investment performance of US equity pension fu nd managers: An empirical investigation. The Journal of Finance, 48(3), 1039-1055.

Connor, G. \& Korajzcyk, R. A. (1986). Performance measurement with the arbitrage pricing theory: A new framework for analysis. Journal of Financial Economics, 15(3), 374 - 394.

Cumby R. \& Glen, J. (1990). Evaluating the performance of international mutual funds. Journal of Finance, 45(2), $497-521$.

Daniel, K., Grinblatt, M., Titman, S., \& Wermers, R. (1997). Measuring mutual fund performance with ch aracteristic-based benchmarks. The Journal of finance, 52(3), 1035-1058.

Fama, E. F. (1972). Components of investment performance. Journal of Finance, 17(3), 551-567.

Gallo J. \& Swanson, P. (1996). Comparative Measures of Performance for US Based International Equity Mutual Funds. Journal of Banking and Finance, 20(10), 1635 - 1650.

Grinblatt M. \& Titman, S. (1988). Mutual fund performance: An analysis of monthly returns. Working Paper, University of California, Los Angeles.

Henriksson, R. D. \& Merton, R. C. (1981). On market timing and investment performance II: Statistical procedures for evaluating forecasting skills. Journal of Business, 54(4), $513-533$.

Henriksson, R. D. (1984). Market timing and mutual fund performance: An empirical investigation. Journal of Business, 57(1), $73-86$.

Investment Company Fact Book (52 $2^{\text {nd }}$ and $53^{\text {rd }}$ editions); A review of trends and activity in the U.S. investment company industry.

Jensen, M. C. (1968). The performance of mutual funds in the period 1945-1964. Journal of Finance, 23(2), $389-416$.

Kadiyala R. \& Lockwood L. (1998). Measuring investment performance with a stochastic parameter regression model. Journal of Banking and Finance, 12(3), 457 - 467.

Keith C., Dirk N. \& Niall O. (2010). The market timing ability of UK mutual funds. Journal of Business Finance \& Accounting, 37(1-2), 270 - 289.

Ken J. S. and Jen C. F. (1979). The Investment performance of mutual funds and empirical investigation of timing selectivity and market efficiency. Journal of Business, 52(2), $263-289$.

Lehmann, B. N., \& Modest, D. M. (1987). Mutual fund performance evaluations: A comparison of benchmarks and benchmarks comparis ons. Journal of Finance, 42(2), 233 - 265.

Merton, R. C. (1981). On market timing and investment performance: An equilibrium theory of Value for market forecasts. Journal of Business, 54, $363-406$.

Nalini, P. T. (2006). Market timing abilities and mutual fund performance - An empirical investigation into equity linked saving schemes. VilakshanXIMB Journal of Management, 127 - 138.

Nikolaos, P. (2002). Market timing and selectivity: An empirical investigation into the features of Greek mutual fund managers. The Journal of Applied Business Research, 18(3), 97-108

Sanjay, S. \& Manoj, J. (2008). On stock selection skill and market timing abilities of mutual fund managers in India. International Research journal of finance \& economics, 15, $307-317$.

SEC annual reports: 2007, 2008, 2009, 2010, 2011 and 2012 editions.

Sinclair, N. A. (1990). Market timing ability of pooled superannuation funds. Accounting and Finance, $51-65$.

Surinder, K. M. (2011). Market Timing Ability of Indian Mutual Funds. VSRD International Journal of B usiness \& Management Research, 1(7), 416-427.

Tihana Š. (2013). Market timing ability of mutual funds with tests applied on several Croatian funds. Croatian Operational Research Review (CRORR), 4, 176 - 186.

Tkac, P. A. (2001). The Performance of Open-end International Mutual Funds. Atlanta Fed's Research Department, Federal Reserve Bank of Atlanta Economic Review, $3^{\text {rd }}$ Quarter 2001

Treynor, J. L. \& Mazuy, K. (1966). Can Mutual Funds Outguess the Market? Harvard Business Review, 44, $131-136$.

Treynor, J. L., \& Black, F. (1973). How to Use Security Analysis to Improve Portfolio Selection. Journal of Business, 46, $66-86$.

Veite, T. \& Cheney, J. M. (1982). Are mutual funds market timers? Journal of Portfolio Management, 8, 35-42. 